Polymer Journal, Vol. 38, No. 10, pp. 1023-1034 (2006)

(C) 2006 The Society of Polymer Science, Japan

\title{
2D NMR Analysis of Acrylonitrile/2-Methoxyethyl Acrylate Copolymers Synthesized by Atom Transfer Radical Polymerization
}

\author{
A. S. BRAR ${ }^{\dagger}$ and Tripta SAINI \\ Department of Chemistry, Indian Institute of Technology, Delhi, New Delhi-110016, India
}

(Received April 18, 2006; Accepted July 7, 2006; Published August 30, 2006)

\begin{abstract}
The copolymerization of acrylonitrile (A) and 2-methoxyethyl acrylate (M) at three different molar in-feed compositions was carried out under atom transfer radical polymerization (ATRP) conditions using 2-bromopropionitrile (BPN) as initiator and $\mathrm{CuCl} / 2,2^{\prime}$-bipyridine (bpy) as catalyst system in ethylene carbonate at $60^{\circ} \mathrm{C}$. Linear first order kinetics, linearly increasing molecular weight with conversion, and low polydispersities were observed for all the copolymerization. The copolymer compositions, obtained from ${ }^{1} \mathrm{H}$ NMR spectra, were utilized to determine the monomer reactivity ratios $\left(\mathrm{r}_{\mathrm{A}}=1.52\right.$ and $\left.\mathrm{r}_{\mathrm{M}}=0.60\right)$ involved in ATRP. Two-dimensional NMR [Heteronuclear Single Quantum Correlation (HSQC) and Total Correlated Spectroscopy (TOCSY)] experiments in conjunction with onedimensional $\left[{ }^{1} \mathrm{H},{ }^{13} \mathrm{C}\left\{{ }^{1} \mathrm{H}\right\}\right.$, and distortionless enhancement by polarization transfer (DEPT) ] experiments were employed for assigning the complex and overlapping signals to various compositional and configurational sequences. The spectral assignments of carbonyl as well as nitrile carbons were done with the help of heteronuclear multiple bond correlation spectra. [doi:10.1295/polymj.PJ2006014]

KEY WORDS Atom Transfer Radical Polymerization (ATRP) / Gel Permeation Chromatography (GPC) / NMR /
\end{abstract}

In the past decade, controlled/living radical polymerization (CRP) has been the focus of numerous studies with the goal of obtaining well-defined polymers with controlled molecular weight, low polydisperisities, topology, end functionalities, and complex architectures. The progress in this area is very rapid and several effective approaches ${ }^{1-4}$ have been reported. Among all controlled radical polymerization techniques, atom transfer radical polymerization (ATRP) $)^{1,2,5-7}$ has emerged as an effective technique for the synthesis of copolymers of novel architectures. ${ }^{8-10}$ Since its discovery in 1995, ATRP has rapidly attracted growing interest of many researchers and industry because of the versatility in the synthesis of polymers with adjustable molecular weights, low polydispersities, compositions, functionalities, and therefore specific properties. It has shown to be an efficient method for the controlled polymerization of wide range of monomers ${ }^{11-27}$ without being affected by the functionalities present in the monomer, initiator or the solvent.

Our group has reported the synthesis of different acrylonitrile copolymers ${ }^{28,29}$ under ATRP conditions. However, so far no attempts have been made for copolymerizing acrylonitrile with 2-methoxyethyl acrylate. Acrylonitrile based copolymers have been successfully applied as membrane materials ${ }^{30-34}$ for hemodialysis, ultrafilteration and enzyme immobilization. Moreover, the polymers based on 2-methoxyethyl acrylate $^{35,36}$ showed excellent blood compatibility with platelets, white blood cells, coagulation system and complement system; based on these studies these copolymers have been applied as a coating material to oxygenators. The excellent blood compatibility of 2-methoxyethyl acrylate makes it a potential comonomer. Thus, combining these two classes of monomers would be interesting from the point of fundamental polymerization studies as well as material properties. The controlled polymerization of acrylonitrile and 2methoxyethyl acrylate is of enormous importance as most of the industrial applications require well-defined products, for which ATRP can be well-utilized.

During copolymerization, the two reacting monomers are not incorporated into the polymer chains in the same proportion as in the initial comonomer feed. It is due to the different reactivity of two monomers towards the growing chain ends. Reactivity ratios and monomer in-feed ratio play a very important role in determining the structure of copolymers. In conventional radical polymerization difference in the reactivity ratio of the monomers lead to variation of composition among the polymer chains. While in ATRP, due to slow initiation and negligible termination, essentially every chain survives from the very beginning to the final stages of polymerization. Any variation of monomer feed along with reactivity ratio differences results in differences in the rates of incorporation of monomer. Therefore, the changes in the instan-

${ }^{\dagger}$ To whom correspondence should be addressed (Tel: +91-11-26591377, Fax: +91-11-25195693, E-mail: asbrar@chemistry.iitd.ernet.in). 
taneous composition arising from these variations are reflected along all the chains, ${ }^{28,29,37,38}$ resulting in the synthesis of gradient copolymers. The study of the arrangement of monomer units in these types of copolymers will be important as well as interesting, to understand the physical properties of copolymers ${ }^{39}$ such as glass transition temperature, morphology, and the crystallinity, which are greatly influenced by the composition, molecular weight, molecular weight distribution, and sequence distribution. ${ }^{40-43}$

High resolution NMR spectroscopy has proven to be one of the most informative techniques for the analysis of sequence distribution in copolymers ${ }^{49-51}$ as the chemical shift values are sensitive to the configurational structure in sequences of monomer units. 2D NMR techniques, in particular, heteronuclear correlation experiments are being utilized for the microstructural analysis of polymers to a great extent. ${ }^{28,37,52-56}$ Rinaldi et al. ${ }^{53,54}$ have employed the usage of multi-dimensional NMR techniques for polymer analysis. Our group has extensively investigated the microstructure of copolymer systems synthesized by ATRP ${ }^{28,37,52}$ using various $2 \mathrm{D}$ NMR techniques.

This article reports the synthesis of well-controlled acrylonitrile-2-methoxyethyl acrylate (A/M) copolymers under ATRP conditions using BPN as initiator and $\mathrm{CuCl} /$ bpy as catalyst system in ethylene carbonate at $60^{\circ} \mathrm{C}$. A comprehensive microstructure analysis of these copolymers is being presented using 2D [heteronuclear single quantum coherence (HSQC), total correlated spectroscopy (TOCSY), and heteronuclear multiple bond correlation (HMBC)] NMR in conjunction with $1 \mathrm{D}\left({ }^{1} \mathrm{H},{ }^{13} \mathrm{C}\left\{{ }^{1} \mathrm{H}\right\}\right.$, DEPT) NMR techniques.

\section{EXPERIMENTAL}

\section{Materials}

Acrylonitrile (AN) (CDH, 99\%) and 2-methoxyethyl acrylate (MEA) (Aldrich, 98\%) were passed through alumina column to remove inhibitor, vacuum distilled and kept below $5{ }^{\circ} \mathrm{C}$ prior to use. 2-Bromopropionitrile (BPN) (Aldrich, 97\%), $\mathrm{CuCl}$ (Aldrich, 97\%) was used as received. 2,2'-bipyridine (bpy) $(\mathrm{CDH}, 99.5 \%)$ was recrystallized from acetone dried in vacuum before use.

\section{Polymerization}

Three different series of acrylonitrile/2-methoxyethyl acrylate (A/M) copolymers, corresponding to different in-feed ratios $0.30 / 0.70,0.45 / 0.55$, and 0.60/0.40 (A/M), were synthesized under ATRP conditions in ethylene carbonate at $60^{\circ} \mathrm{C}$, using 2-bromopropionitrile (BPN) as initiator and $\mathrm{CuCl} / 2,2^{\prime}$-bipyridine (bpy) as the catalyst system. The molar ratio for polymerization was taken as $[\text { Monomers }]_{0}:[\mathrm{BPN}]_{0}$ :
$[\mathrm{CuCl}]_{0}:[\mathrm{bpy}]_{0}=200: 1: 0.5: 1.5$. All polymerization reactions were performed using standard Schlenck line techniques under a nitrogen atmosphere. In a typical procedure, calculated amounts of monomers along with copper chloride $(\mathrm{CuCl})$, and ligand (bpy) were added to the round bottom flask along with ethylene carbonate. The system was degassed by three vacuum-nitrogen cycles and stirred at the desired temperature for $10 \mathrm{~min}$ for the formation of catalyst. The calculated amount of purged initiator (BPN) was then added to the flask. The system was again degassed by three vacuum-nitrogen cycles and then sealed with septum. The flask was then placed in an oil bath maintained at $60^{\circ} \mathrm{C}$. The progress of the polymerization was monitored by the withdrawal of samples at timed intervals. The contents were then diluted with tetrahydrofuran (THF) and subsequently passed through a neutral alumina column to remove the catalyst. The excess THF was removed by rotary evaporation and the polymer was precipitated in large excess of methanol/water (1:1) system. The precipitated polymer was dried in a vacuum oven at $30^{\circ} \mathrm{C}$ until constant weight was reached.

\section{Characterization}

The monomer conversion was determined gravimetrically. The molecular weight $\left(M_{\mathrm{n}}\right)$ and the polydispersity index $\left(M_{\mathrm{w}} / M_{\mathrm{n}}\right)(\mathrm{PDI})$ were measured using Gel Permeation Chromatography (GPC) equipped with a Waters 501 pump with guard column and a Waters 410 RI detector against polystyrene standards. The HPLC grade tetrahydrofuran (THF) was used as eluent at the flow rate of $0.5 \mathrm{~mL} / \mathrm{min}$ at room temperature. ${ }^{1} \mathrm{H}$ NMR spectra was utilized to determine the copolymer composition of all the polymer samples withdrawn at different conversions for each infeed molar ratio. All the NMR measurements $\left({ }^{1} \mathrm{H}\right.$, ${ }^{13} \mathrm{C}\left\{{ }^{1} \mathrm{H}\right\}$, DEPT, HSQC, TOCSY, HMBC) were done at $25^{\circ} \mathrm{C}$ on about $10 \%$ polymer solutions (Table I) in $\mathrm{CDCl}_{3}$ using Bruker DPX-300 spectrometer operating at $300.15 \mathrm{MHz}$ for ${ }^{1} \mathrm{H}$ and at $75.5 \mathrm{MHz}$ for ${ }^{13} \mathrm{C}$ nuclei using standard pulse sequences as reported in our earlier publications. ${ }^{55}$ The signal intensities of the spectra peaks were measured from the integrated peak areas calculated with an electronic integrator.

Table I. 2D NMR measurements on the polymer samples having different copolymer compositions at different conversions

\begin{tabular}{ccc}
\hline $\begin{array}{c}\text { Monomer } \\
\text { infeed ratio } \\
\mathrm{A} / \mathrm{M}\end{array}$ & $\begin{array}{c}\text { Copolymer } \\
\text { composition } \\
\left(\mathrm{F}_{\mathrm{A}}\right)\end{array}$ & $\begin{array}{c}\text { Percentage } \\
\text { conversion } \\
(\%)\end{array}$ \\
\hline $0.30 / 0.70$ & 0.35 & 68 \\
$0.45 / 0.55$ & 0.50 & 64 \\
$0.60 / 0.40$ & 0.65 & 66 \\
\hline
\end{tabular}




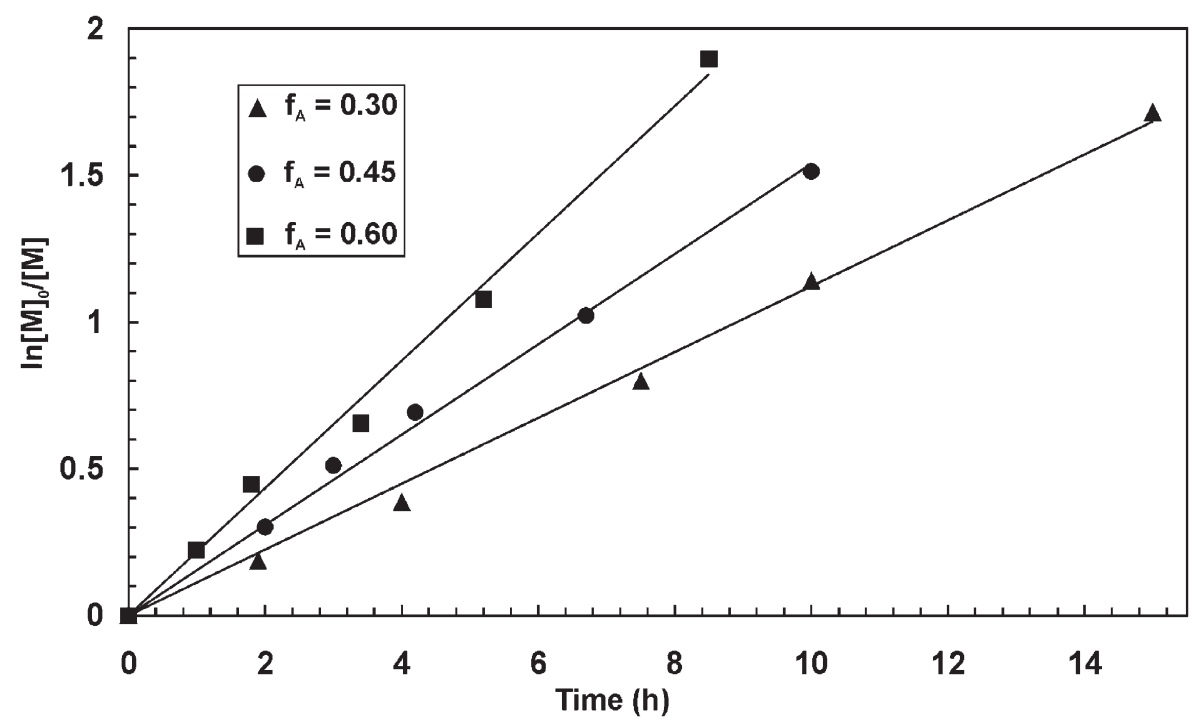

Figure 1. Semilogarithmic kinetic plot for the copolymerization of acrylonitrile (A) and 2-methoxyethyl acrylate (M) at several monomer feed conditions.

\section{RESULTS AND DISCUSSION}

Based on the knowledge obtained from the available literature on atom transfer radical polymerization (ATRP) of acrylonitrile copolymers, ${ }^{28,57-59}$ the copolymerization of acrylonitrile (A) and 2-methoxyethyl acrylate $(\mathrm{M})$ was performed using 2-bromopropionitrile (BPN) as initiator with $\mathrm{CuCl} / 2,2^{\prime}$-bipyridine (bpy) as catalyst system at $60^{\circ} \mathrm{C}$ ([Monomers $]_{0}:[\mathrm{BPN}]_{0}$ : $\left.[\mathrm{CuCl}]_{0}:[\mathrm{bpy}]_{0}=200: 1: 0.5: 1.5\right)$. The polymerizations were conducted in homogeneous conditions with ethylene carbonate as solvent to increase the solubility of the catalyst and the polymer. The first order kinetic plots for the atom transfer radical copolymerization of $\mathrm{A}$ and $\mathrm{M}$ for three different in-feed ratios $(\mathrm{A} / \mathrm{M}=$ $0.30 / 0.70,0.45 / 0.55$, and $0.60 / 0.40)$ are displayed in Figure 1 . In all the cases, $\ln [\mathrm{M}]_{0} /[\mathrm{M}]$ increased nearly linearly with time, indicating that the copolymerization obey an approximately first order dependence on total monomer concentration.

The kinetic profiles suggest fast initiation and negligible termination. This conclusion was further supported by the relatively low polydispersities $[1.1<$ $\left.\left(M_{\mathrm{w}} / M_{\mathrm{n}}\right)<1.4\right]$ of the obtained $\mathrm{A} / \mathrm{M}$ copolymers, as shown in Figure 2. The molecular weights of A/M copolymers, determined by gel permeation chromatography (GPC), showed linear variation with total monomer conversion indicating towards the controlled nature of copolymerization.

\section{Copolymer Compositions and Reactivity Ratio Deter- mination}

The copolymer compositions were determined using ${ }^{1} \mathrm{H}$ NMR spectra by correlating the relative inten- sity of signals of the oxymethylene $\left(\mathrm{O}^{1} \mathrm{CH}_{2}\right)$ protons in the $\mathrm{M}$ unit and rest of the protons in $\mathrm{A}+\mathrm{M}$ unit using the following expression:

$$
\mathrm{F}_{\mathrm{A}}=\frac{2 \mathrm{X}-8 \mathrm{Y}}{2 \mathrm{X}-5 \mathrm{Y}}
$$

where, $\mathrm{F}_{\mathrm{A}}$ is the molar fraction of acrylonitrile unit in the copolymer, $\mathrm{Y}$ is the area under the resonance signal of oxymethylene $\left(\mathrm{O}^{1} \mathrm{CH}_{2}\right)$ protons from the $\mathrm{M}$ unit, and $\mathrm{X}$ is the area under the resonance signals of the rest of the protons from $\mathrm{A}+\mathrm{M}$ unit.

For polymerizations involving high conversions, accurate values of reactivity ratios are not obtained using low conversion methods. ${ }^{60,61}$ Hence, the reactivity ratios were optimized using the least square methodology described elsewhere. ${ }^{62}$ The theoretical outfeeds at high conversions were calculated by following the model proposed by Heatley et al. ${ }^{63}$ and Mao and Huglin ${ }^{64}$ and optimization was done as described earlier. ${ }^{28,37,52}$ The optimized reactivity ratio values were found to be $r_{A}=1.52$ and $r_{M}=0.60$, which were in good agreement with those reported earlier. ${ }^{28}$

Any variation in the relative concentration of monomer may incorporate gradiency in the copolymer chains due to different monomer reactivity ratios. Due to this, the reaction mixture becomes more depleted in the more reactive monomer as it gets incorporated into the copolymer chains to a greater extent leading to the compositional drift along the polymer chains. Figure 3 shows $F_{A}$ as a function of the conversion for three different in-feed compositions $\left(f_{A}\right)$. The variation of $F_{A}$ with conversion indicated the presence of slight gradiency in the copolymer composition. Good agreement between the theoretical and experimental values indicates that the free radical mechanism is being followed. 


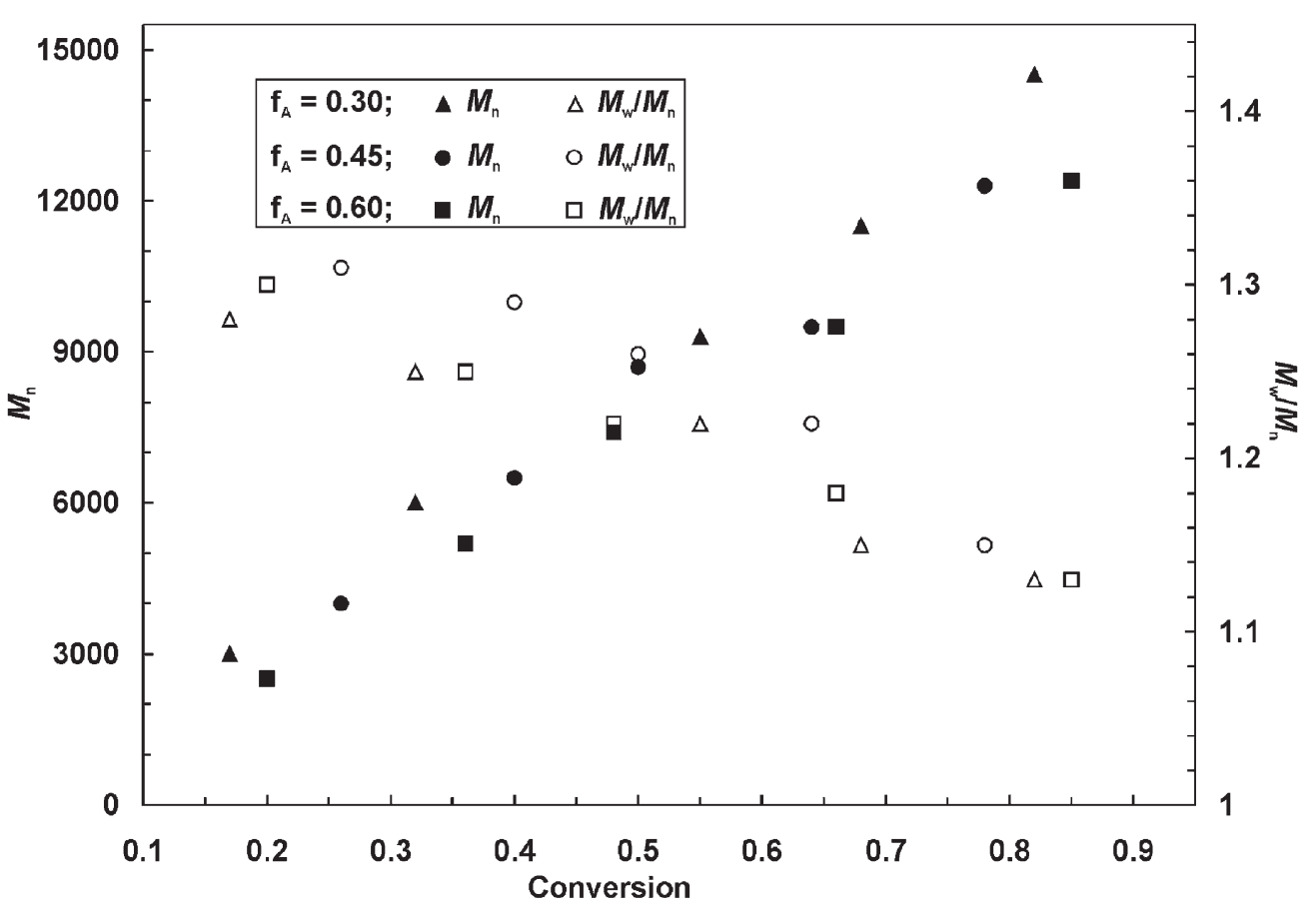

Figure 2. Molecular weight $\left(M_{\mathrm{n}}\right)$ and polydispersity $\left(M_{\mathrm{w}} / M_{\mathrm{n}}\right) v s$. total monomer conversion for the copolymerization of acrylonitrile (A) and 2-methoxyethyl acrylate $(\mathrm{M})$ at several monomer feed conditions.

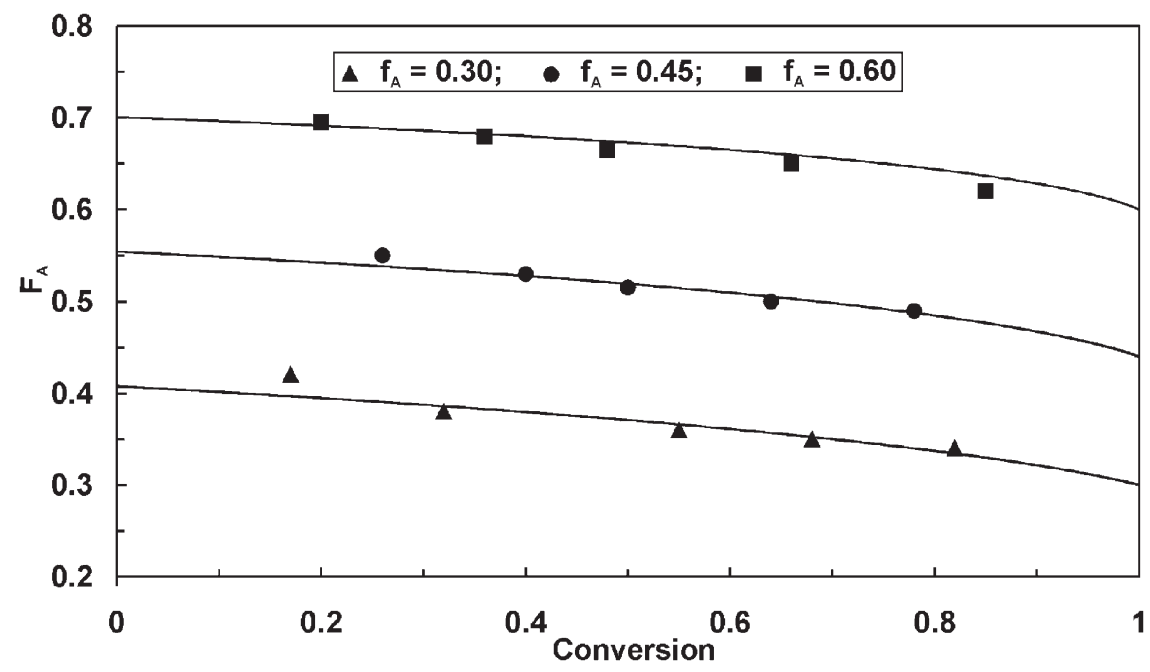

Figure 3. Variation of copolymer composition $\left(\mathrm{F}_{\mathrm{A}}\right)$ as a function of conversion of $\mathrm{A} / \mathrm{M}$ copolymers for different in-feed compositions.

\section{${ }^{13} C\left\{{ }^{1} H\right\}$ NMR Spectral Studies}

The ${ }^{13} \mathrm{C}\left\{{ }^{1} \mathrm{H}\right\}$ NMR spectra of A/M copolymer for $\mathrm{F}_{\mathrm{A}}=0.50$ with the assignments of various resonance signals are shown in Figure 4. The assignments were done by comparison with the ${ }^{13} \mathrm{C}\left\{{ }^{1} \mathrm{H}\right\}$ NMR spectra of the corresponding homopolymers. The carbonyl carbon resonance of the $\mathrm{M}$ unit appears around 172.4$174.6 \mathrm{ppm}$, while the resonance signals in 118.6$121.0 \mathrm{ppm}$ region were assigned to nitrile carbon from A unit. Both the carbon resonances were highly complex and overlapping, indicating their sensitivity towards compositional and configurational sequences. The spectral region around $10-70 \mathrm{ppm}$ was assigned to the aliphatic carbons of $\mathrm{A}$ and $\mathrm{M}$ unit with the help of DEPT-135 (Figure 5) in conjunction with ${ }^{13} \mathrm{C}\left\{{ }^{1} \mathrm{H}\right\}$ NMR spectrum as in DEPT-135 the methylene carbon signal appear in negative phase while the methine and methyl carbon signals appear in the positive phase.

The $-\mathrm{O}^{1} \mathrm{CH}_{2},-\mathrm{O}^{2} \mathrm{CH}_{2},-\mathrm{OCH}_{3}$ and methine $\mathrm{CH}$ carbon of the $\mathrm{M}$ unit appear as singlet around 63.9, $70.1,58.9$, and $41.0 \mathrm{ppm}$, respectively, reflecting their insensitivity to the compositional and configurational sequences. The spectral region around 32.1-36.3 ppm was assigned to the backbone methylene carbon resonance signals of both A and M units. Due to overlap- 


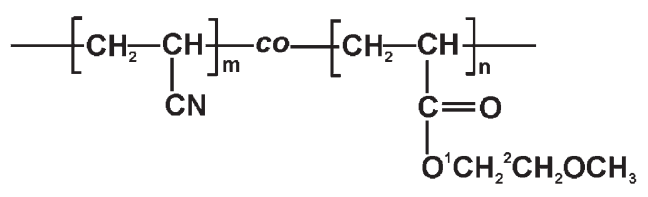

A
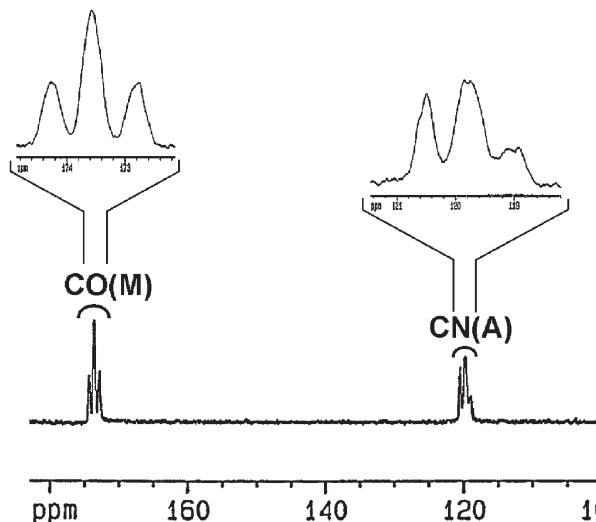

M

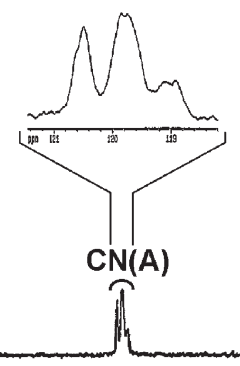

120

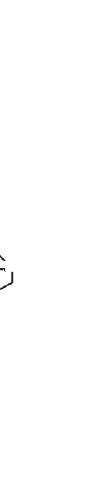

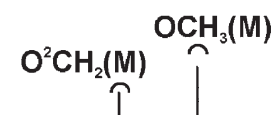


(a)

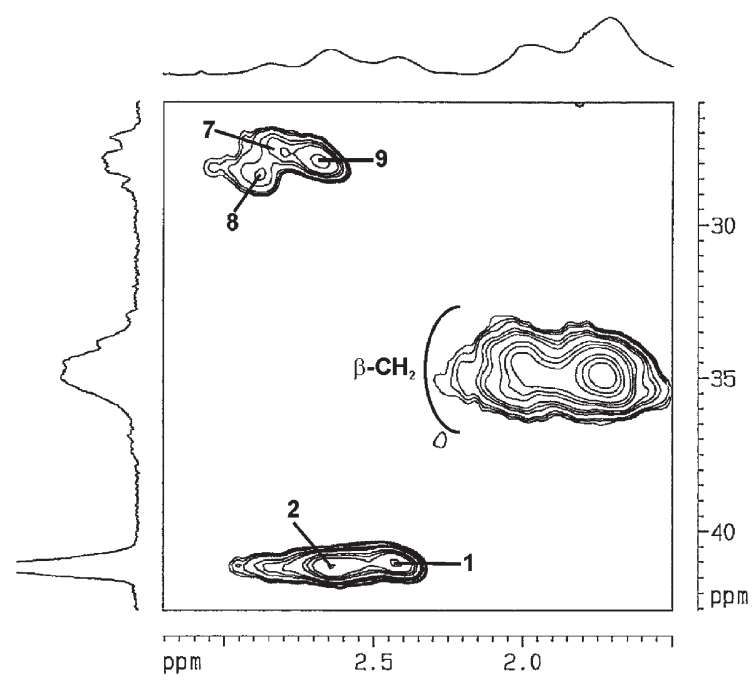

(b)
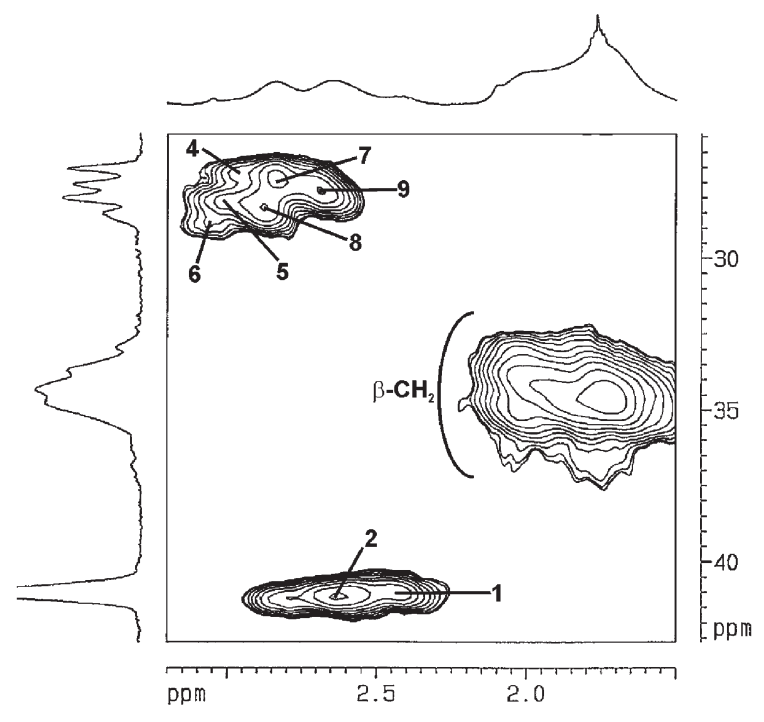

(c)

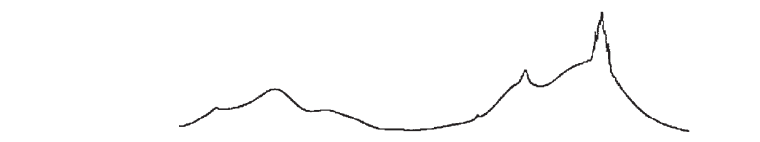

)

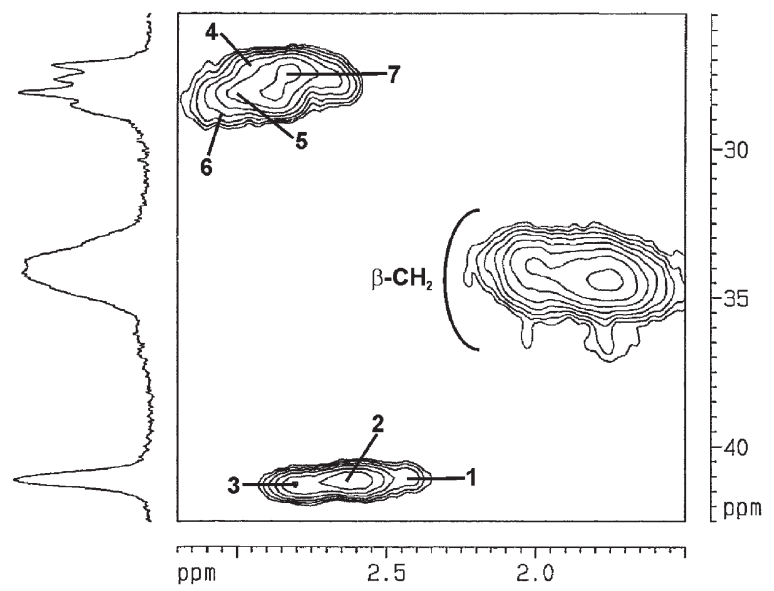

Figure 6. $2 \mathrm{D}$ HSQC NMR spectra of A/M copolymers showing the methine region, having (a) $\mathrm{F}_{\mathrm{A}}=0.35$, (b) $\mathrm{F}_{\mathrm{A}}=0.50$, and (c) $\mathrm{F}_{\mathrm{A}}=0.65$

2D HSQC spectra of A/M copolymer representing the methine region for three different compositions are shown in Figure 6.

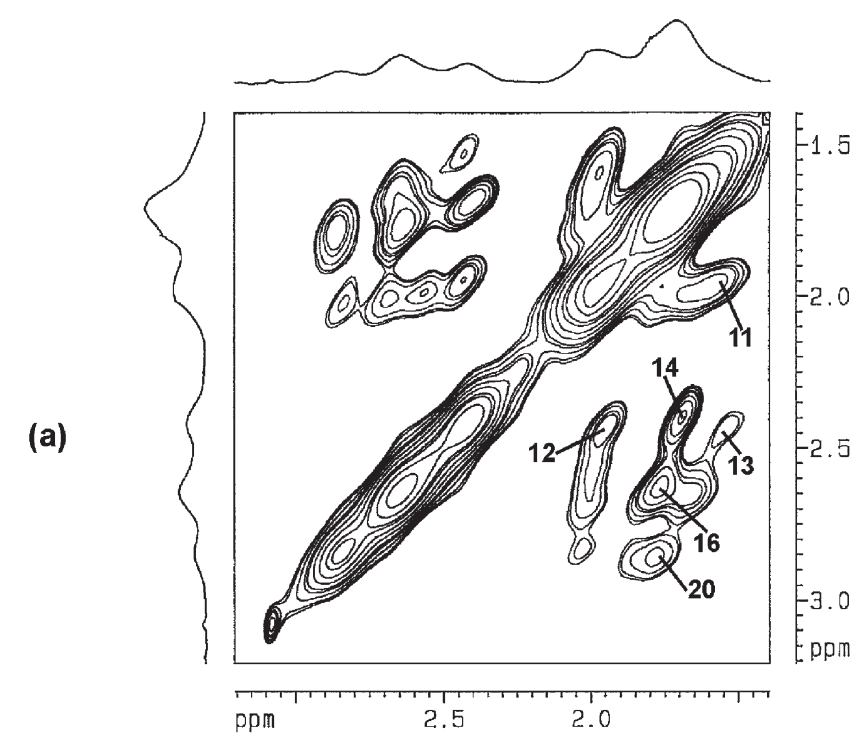

(b)

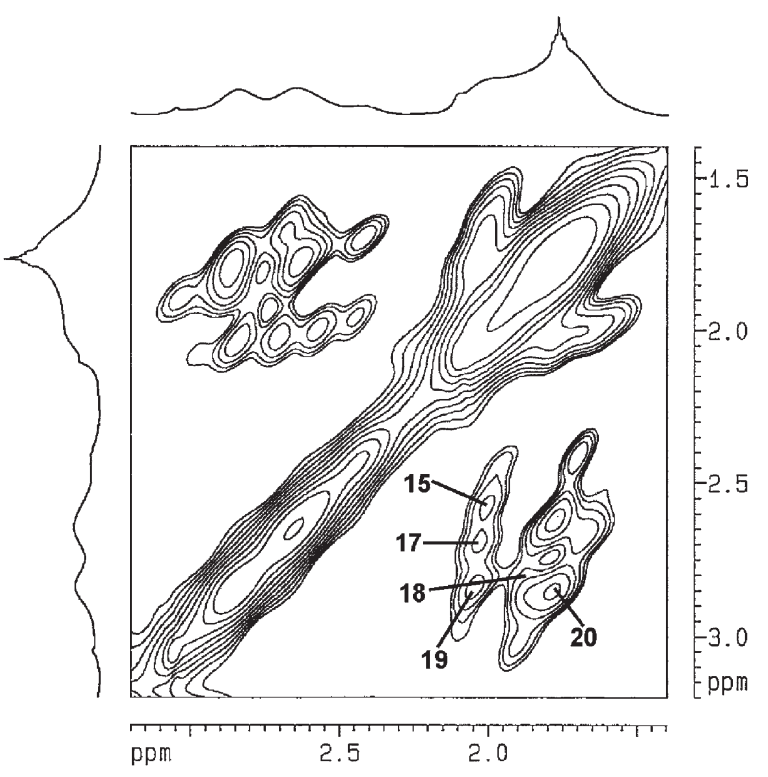

(c)
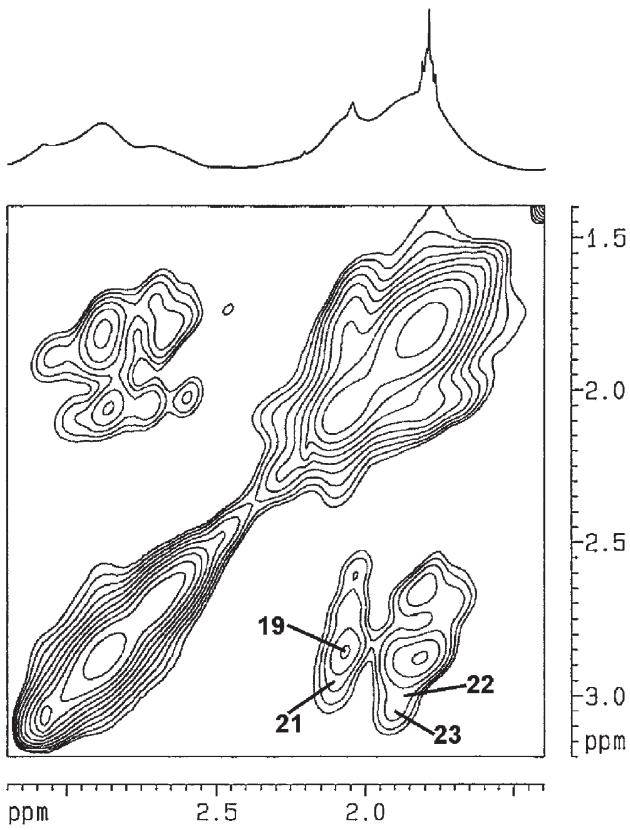

Figure 7. 2D TOCSY NMR spectra of A/M copolymers having (a) $\mathrm{F}_{\mathrm{A}}=0.35$, (b) $\mathrm{F}_{\mathrm{A}}=0.50$, and (c) $\mathrm{F}_{\mathrm{A}}=0.65$. 
The methine carbon of $\mathrm{M}$ unit showed three cross peaks 1-3 which varied in intensity with the copolymer composition and hence were attributed to MMM, AMM and AMA triads, respectively. On similar basis, the cross peaks 4-6 and 7-8 were assigned to AAA and AAM triads, respectively. The variation of copolymer composition does not impart any effect on the intensity of these cross peaks, hence were attributed to the configurational sensitivity within these triads. Using this approach, the cross peaks 4, 5, and 6 were assigned to AmAmA, AmArA, and ArArA triads on the basis of HSQC spectra of polyacrylonitrile as shown in Figure 6b. In AAB triad region, the cross peaks 7 and 8 were ascribed to AmAM and ArAM, respectively. The cross peak 9 was assigned to MAM triad sequence. Thus, the overlapping methine carbon region of both $\mathrm{A}$ and $\mathrm{M}$ were assigned to various compositional and configurational sequences. The spectral assignments are given in Table II.

2D HSQC spectra revealed that the methine protons in $\mathrm{M}$ unit lie in the range of 2.4-2.8 ppm and those in

Table II. Spectral assignments of methine region based on 2D HSQC spectra

\begin{tabular}{ccc}
\hline Peak & $\begin{array}{c}\text { Peak } \\
\text { assignments }\end{array}$ & $\begin{array}{c}\text { Peak position } \\
\left(2 \mathrm{D} \text { HSQC; }{ }^{13} \mathrm{C} /{ }^{1} \mathrm{H} ; \mathrm{ppm}\right)\end{array}$ \\
\hline 1 & MMM & $41.02 / 2.43$ \\
2 & AMM & $41.12 / 2.63$ \\
3 & AMA & $41.24 / 2.80$ \\
4 & AmAmA & $27.21 / 2.95$ \\
5 & AmArA & $28.10 / 3.00$ \\
6 & ArArA & $28.91 / 3.05$ \\
7 & AmAM & $27.49 / 2.83$ \\
8 & ArAM & $28.30 / 2.87$ \\
9 & MAM & $27.78 / 2.68$ \\
\hline
\end{tabular}

A unit lie in the spectral region of $2.6-3.1 \mathrm{ppm}$ in the ${ }^{1} \mathrm{H}$ NMR spectra.

\section{D TOCSY Spectral Analysis}

2D TOCSY spectral analysis was carried out to confirm the assignments made with 2D HSQC spectra. Figure 7 shows the 2D TOCSY spectra of $\mathrm{A} / \mathrm{M}$ copolymers of different compositions representing the 1, 3-bond order couplings between the methine and methylene protons of both A and $\mathrm{M}$ units in the copolymers. The cross correlation peak 11 was obtained due to the coupling between the non-equivalent $\mathrm{Ha}$ and $\mathrm{Hb}$ methylene protons of $\mathrm{MmM}$ dyad. The cross-correlation peaks 12-23 were attributed to the couplings of methine protons of $\mathrm{A}$ and $\mathrm{M}$ centered triads with methylene protons. The cross peaks 12 and 13 were due to the coupling of $\mathrm{MmMmM}$ triad of methine protons with the non-equivalent $\mathrm{Ha}$ and $\mathrm{Hb}$ methylene protons of MmM dyad, respectively. The MrM methylene protons coupled with MmMrM/ MrMrM methine protons resulting in a cross peak 14 as shown in Figure 7a. The cross peak 15 was assigned to the coupling of MmMA methine protons with $\mathrm{MmM}$ (Ha) methylene protons. Following the same analogy, the cross peaks 15-20 were assigned as shown in Figure 7b. As the content of A unit increases in the A/M copolymers, the cross peaks due to the coupling of AAA triad with methylene protons were observed only at higher $\mathrm{F}_{\mathrm{A}}$ (Figure 7c).

On the basis of 2D TOCSY spectra of polyacrylonitrile, the cross peak 21 was assigned to the coupling of methine protons of AmAmA triad with Ha methylene protons of AmA dyad. Using similar approach, the cross peaks 22 and 23 were assigned. All the spectral assignments made for the various resonances based on 2D TOCSY spectra are listed in Table III.

Table III. Cross-correlations between non-equivalent geminal protons of methylene and between methine and methylene protons with assignments in $\mathrm{A} / \mathrm{M}$ copolymers

\begin{tabular}{|c|c|c|c|}
\hline Peak & $\begin{array}{l}\text { Type of proton } \\
(\mathrm{ppm})\end{array}$ & $\begin{array}{l}\text { Coupled to } \\
\text { (ppm) }\end{array}$ & $\begin{array}{l}\text { Cross correlation } \\
\text { peak position } \\
\left({ }^{1} \mathrm{H} /{ }^{1} \mathrm{H} ; \mathrm{ppm}\right)\end{array}$ \\
\hline 11 & $\mathrm{CH}_{2}$ of $\mathrm{MmM}(\mathrm{Ha})$ & $\mathrm{CH}_{2}$ of $\mathrm{MmM}(\mathrm{Hb})$ & $1.95 / 1.54$ \\
\hline 12 & $\mathrm{CH}$ of $\mathrm{MmMmM}$ & $\mathrm{CH}_{2}$ of $\mathrm{MmM}(\mathrm{Ha})$ & $2.44 / 1.95$ \\
\hline 13 & $\mathrm{CH}$ of $\mathrm{MmMmM}$ & $\mathrm{CH}_{2}$ of $\mathrm{MmM}(\mathrm{Hb})$ & $2.44 / 1.54$ \\
\hline 14 & $\mathrm{CH}$ of $\mathrm{MmMrM} / \mathrm{MrMrM}$ & $\mathrm{CH}_{2}$ of $\mathrm{MrM}$ & $2.40 / 1.70$ \\
\hline 15 & $\mathrm{CH}$ of MmMA & $\mathrm{CH}_{2}$ of $\mathrm{MmM}(\mathrm{Ha})$ & $2.57 / 1.98$ \\
\hline 16 & $\mathrm{CH}$ of MrMA & $\mathrm{CH}_{2}$ of $\mathrm{MrM} / \mathrm{MmA}(\mathrm{Hb})$ & $2.63 / 1.76$ \\
\hline 17 & $\mathrm{CH}$ of $\mathrm{MMmA} / \mathrm{MmAM}$ & $\mathrm{CH}_{2}$ of $\mathrm{AmM}(\mathrm{Ha})$ & $2.70 / 2.03$ \\
\hline 18 & $\mathrm{CH}$ of ArMA & $\mathrm{CH}_{2}$ of $\mathrm{ArM}$ & $2.80 / 1.87$ \\
\hline 19 & $\mathrm{CH}$ of AmMA/AAmM & $\mathrm{CH}_{2}$ of $\mathrm{AmM}(\mathrm{Ha})$ & $2.85 / 2.05$ \\
\hline 20 & $\mathrm{CH}$ of AmMA/AAmM & $\mathrm{CH}_{2}$ of $\mathrm{AmM}(\mathrm{Hb})$ & $2.83 / 1.77$ \\
\hline 21 & $\mathrm{CH}$ of $\mathrm{AmAmA}$ & $\mathrm{CH}_{2}$ of $\mathrm{AmA}(\mathrm{Ha})$ & $2.95 / 2.10$ \\
\hline 22 & $\mathrm{CH}$ of AmArA & $\mathrm{CH}_{2}$ of $\mathrm{AmA}(\mathrm{Hb})$ & $3.00 / 1.87$ \\
\hline 23 & $\mathrm{CH}$ of $\mathrm{ArArA}$ & $\mathrm{CH}_{2}$ of $\mathrm{ArA}$ & $3.05 / 1.90$ \\
\hline
\end{tabular}




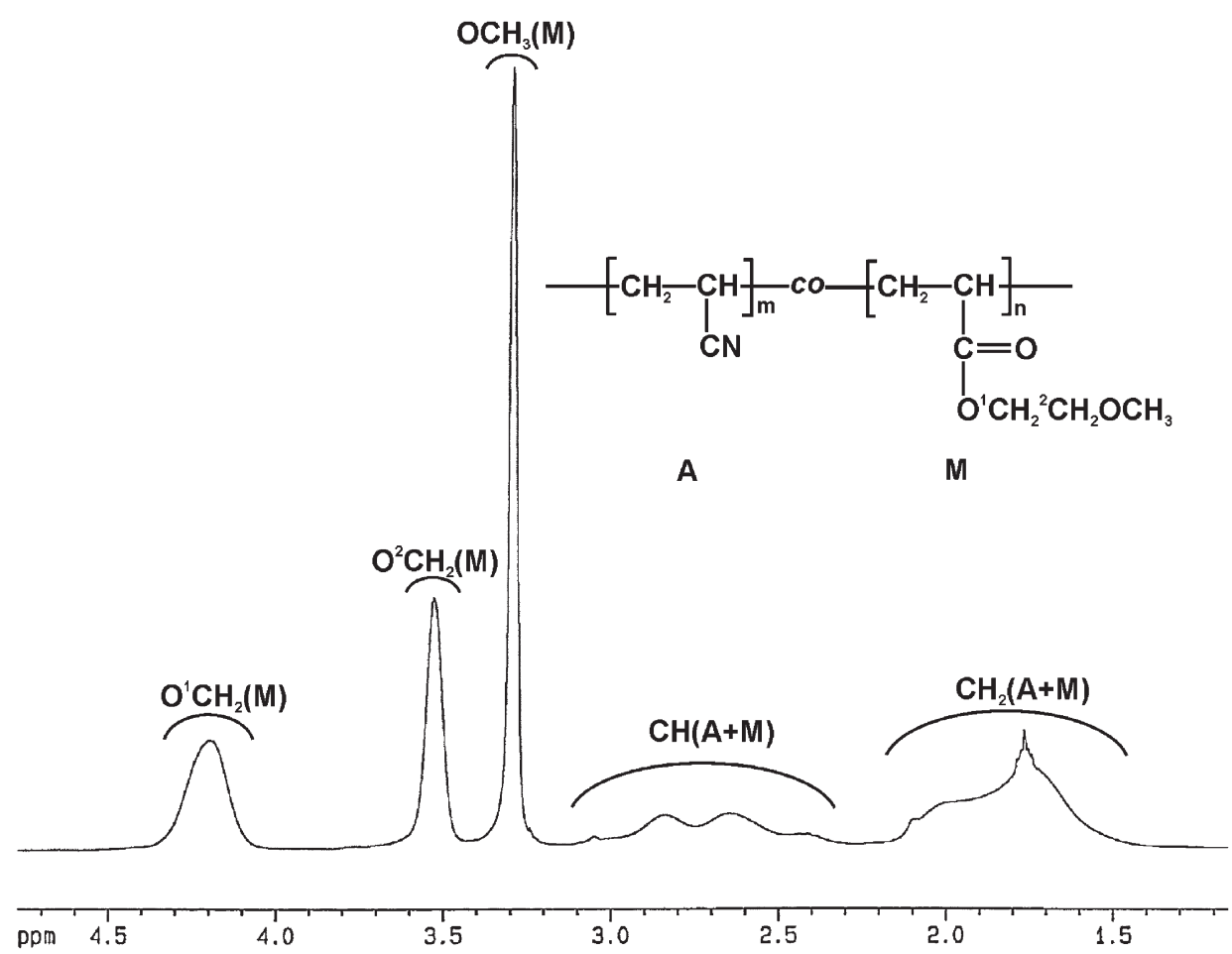

Figure 8. The assigned ${ }^{1} \mathrm{H}$ NMR spectrum of $\mathrm{A} / \mathrm{M}$ copolymer having $\mathrm{F}_{\mathrm{A}}=0.50$ in $\mathrm{CDCl}_{3}$ at $25^{\circ} \mathrm{C}$.

On the basis of assignments made using 2D HSQC in conjunction with $2 \mathrm{D}$ TOCSY spectra, ${ }^{1} \mathrm{H}$ NMR spectrum was assigned completely and shown in Figure 8.

\section{D HMBC Spectral Analysis}

Both the carbonyl and nitrile carbons, being quaternary carbons do not show any coupling in 2D HSQC spectra, so we resort to 2D HMBC spectral studies for investigating the compositional as well as configurational sensititivity of the carbonyl and nitrile carbons. ${ }^{1} \mathrm{H}$ NMR spectra, completely assigned with the help of 2D HSQC and TOCSY spectra, was utilized for analyzing 2D HMBC spectra. The cross peaks assigned from the HMBC spectra for the carbonyl (Figure 9) and nitrile regions (Figure 10) are listed in Table IV.

Considering the coupling of carbonyl carbon with methine protons, only $\mathrm{M}$ centered triads will be observed. The cross peaks 31,32 , and 33 were attributed to the coupling of the carbonyl carbons with the methine protons in the MrMrM, MmMrM, and MmMmM triads, respectively. Similarly, the cross peaks 34-36 were assigned as shown in Figure 9a. The cross peaks 37-46 were assigned to the couplings of carbonyl carbon with the adjacent methylene protons. The cross peaks 37, 38, and 39 were assigned to the coupling of MMM triad of carbonyl carbon with $\mathrm{MrM}, \mathrm{MmM}(\mathrm{Ha})$, and $\mathrm{MmM}(\mathrm{Hb})$ methylene protons respectively. On similar lines, the assignments of the cross peaks 40-44 were made. The cross peaks 45 and 46 were due to the couplings of carbonyl carbon (a)

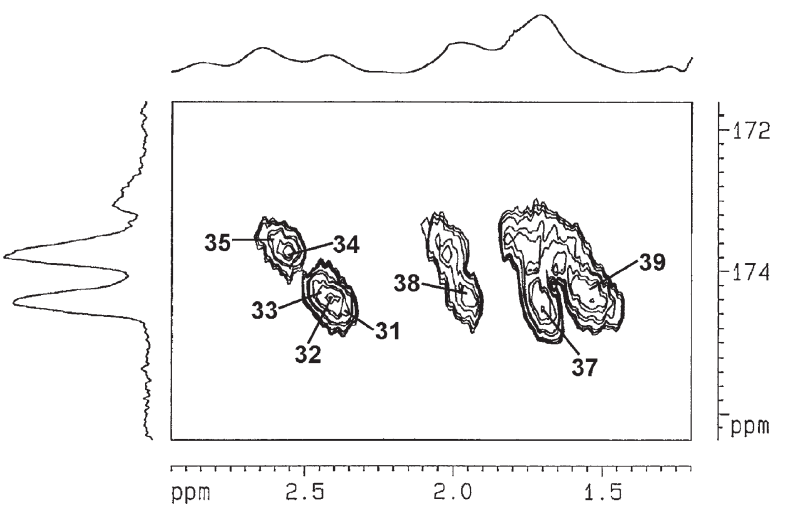

(b)

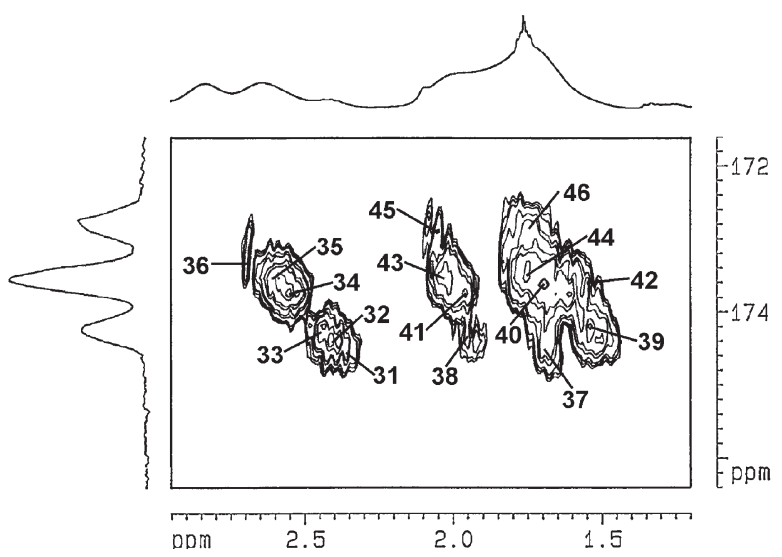

Figure 9. 2D HMBC NMR spectra of $\mathrm{A} / \mathrm{M}$ copolymers showing the carbonyl region for (a) $\mathrm{F}_{\mathrm{A}}=0.35$, and (b) $\mathrm{F}_{\mathrm{A}}=0.50$.

of AMA triad with $\mathrm{Ha}$ and $\mathrm{Hb}$ protons of AmM dyad of methylene protons, respectively (Figure $9 b$ ).

Table V shows the comparison of M-centered triad 
(a)

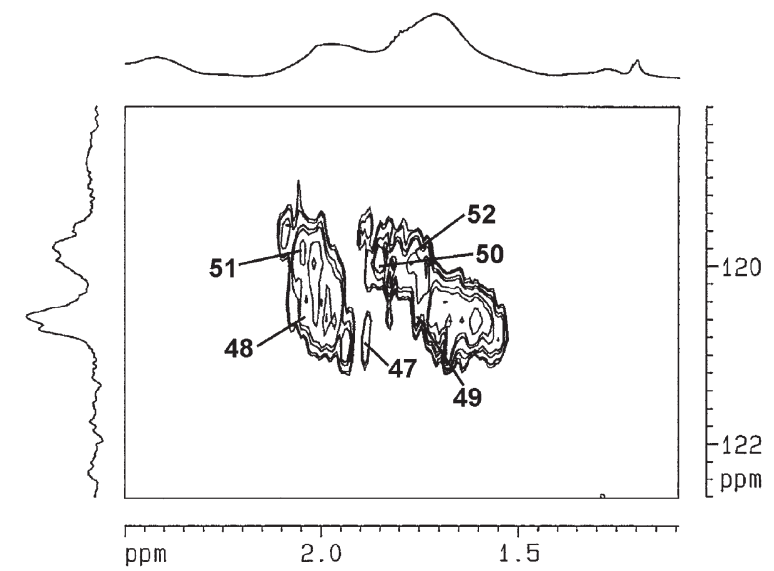

(b)

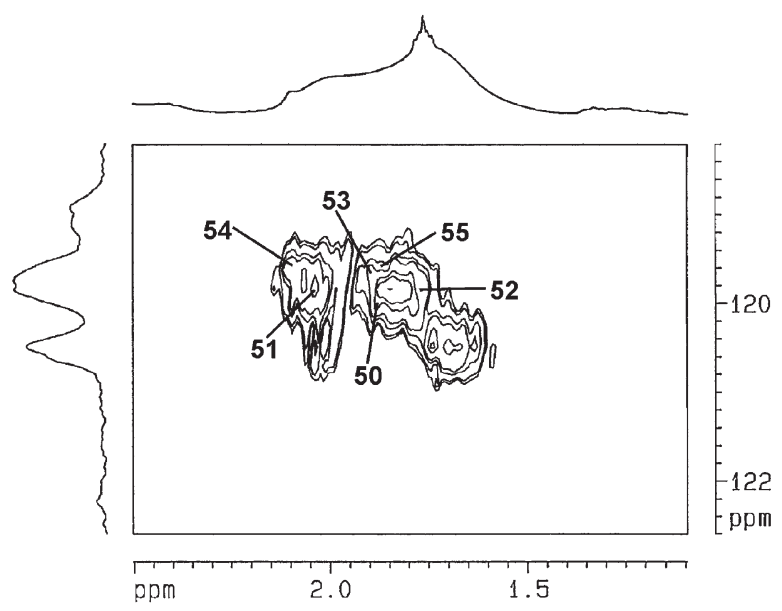

Figure 10. 2D HMBC NMR spectra of A/M copolymers showing the nitrile region, having (a) $\mathrm{F}_{\mathrm{A}}=0.35$, and (b) $\mathrm{F}_{\mathrm{A}}=0.50$.

fractions determined from the carbonyl carbon resonance patterns for different percentage conversion under three different molar in-feed conditions. The theoretical concentrations of various triads were calculated from the reactivity ratios using the methodology described elsewhere. ${ }^{38}$ The experimentally observed M-centered triad fractions were estimated by determining the area under the resonance peaks using the Lorentzian curve-fitting. Curve fitting was done using an electronic integrator. The variation of triad fractions with conversion further confirmed the presence of some gradiency in the copolymer chains. Good agreement was observed between the triad fractions determined theoretically and experimentally, thereby supporting the assignments.

The cross peaks 47-55 were ascribed to the coupling of nitrile carbons with the methylene protons. As nitrile carbon is present only in A unit, hence in this region only A centered triads will be observed. The methylene protons of ArM, AmM (Ha), and AmM ( $\mathrm{Hb})$ dyad coupled with MAM triad of nitrile carbon to give cross peaks 47,48 , and 49 , respectively. Similarly the cross peaks $50-51$ were assigned to
Table IV. Spectral assignments of carbonyl and nitrile carbon region of $\mathrm{A} / \mathrm{M}$ copolymers based on $2 \mathrm{D} \mathrm{HMBC}$ spectra

\begin{tabular}{|c|c|c|c|}
\hline Peak & $\begin{array}{l}\text { Type of carbon } \\
\text { (ppm) }\end{array}$ & $\begin{array}{l}\text { Coupled to } \\
(\mathrm{ppm})\end{array}$ & $\begin{array}{l}\text { Peak position } \\
\text { (2D HMBC; } \\
\left.{ }^{13} \mathrm{C} /{ }^{1} \mathrm{H} ; \mathrm{ppm}\right)\end{array}$ \\
\hline 31 & $\mathrm{CO}$ of $\mathrm{MrMrM}$ & $\mathrm{CH}$ of $\mathrm{MrMrM}$ & $174.58 / 2.36$ \\
\hline 32 & $\mathrm{CO}$ of $\mathrm{MmMrM}$ & $\mathrm{CH}$ of $\mathrm{MmMrM}$ & $174.40 / 2.41$ \\
\hline 33 & $\mathrm{CO}$ of $\mathrm{MmMmM}$ & $\mathrm{CH}$ of $\mathrm{MmMmM}$ & $174.28 / 2.45$ \\
\hline 34 & $\mathrm{CO}$ of MmMA & $\mathrm{CH}$ of MmMA & $173.75 / 2.56$ \\
\hline 35 & CO of MrMA & $\mathrm{CH}$ of MrMA & $173.56 / 2.62$ \\
\hline 36 & $\mathrm{CO}$ of $\mathrm{MMmA}$ & $\mathrm{CH}$ of $\mathrm{MMmA}$ & $173.30 / 2.70$ \\
\hline 37 & $\mathrm{CO}$ of $\mathrm{MMM}$ & $\mathrm{CH}_{2}$ of $\mathrm{MrM}$ & $174.52 / 1.70$ \\
\hline 38 & $\mathrm{CO}$ of $\mathrm{MMM}$ & $\mathrm{CH}_{2}$ of $\mathrm{MmM}(\mathrm{Ha})$ & $174.30 / 1.95$ \\
\hline 39 & $\mathrm{CO}$ of $\mathrm{MMM}$ & $\mathrm{CH}_{2}$ of $\mathrm{MmM}(\mathrm{Hb})$ & $174.25 / 1.54$ \\
\hline 40 & $\mathrm{CO}$ of $\mathrm{AMM}$ & $\mathrm{CH}_{2}$ of $\mathrm{MrM}$ & $173.65 / 1.70$ \\
\hline 41 & $\mathrm{CO}$ of $\mathrm{AMM}$ & $\mathrm{CH}_{2}$ of $\mathrm{MmM}(\mathrm{Ha})$ & $173.72 / 1.96$ \\
\hline 42 & $\mathrm{CO}$ of $\mathrm{AMM}$ & $\mathrm{CH}_{2}$ of $\mathrm{MmM}(\mathrm{Hb})$ & $173.60 / 1.55$ \\
\hline 43 & $\mathrm{CO}$ of $\mathrm{AMM}$ & $\mathrm{CH}_{2}$ of $\mathrm{AmM}(\mathrm{Ha})$ & $173.56 / 2.03$ \\
\hline 44 & $\mathrm{CO}$ of $\mathrm{AMM}$ & $\mathrm{CH}_{2}$ of $\mathrm{AmM}(\mathrm{Hb})$ & $173.48 / 1.76$ \\
\hline 45 & $\mathrm{CO}$ of AMA & $\mathrm{CH}_{2}$ of $\mathrm{AmM}(\mathrm{Ha})$ & $172.91 / 2.05$ \\
\hline 46 & $\mathrm{CO}$ of AMA & $\mathrm{CH}_{2}$ of $\mathrm{AmM}(\mathrm{Hb})$ & $172.85 / 1.75$ \\
\hline 47 & $\mathrm{CN}$ of MAM & $\mathrm{CH}_{2}$ of $\mathrm{ArM}$ & $120.84 / 1.88$ \\
\hline 48 & $\mathrm{CN}$ of MAM & $\mathrm{CH}_{2}$ of $\mathrm{AmM}(\mathrm{Ha})$ & $120.55 / 2.04$ \\
\hline 49 & $\mathrm{CN}$ of MAM & $\mathrm{CH}_{2}$ of $\mathrm{AmM}(\mathrm{Hb})$ & $120.55 / 1.76$ \\
\hline 50 & $\mathrm{CN}$ of MAA & $\mathrm{CH}_{2}$ of $\mathrm{ArM}$ & $120.03 / 1.86$ \\
\hline 51 & $\mathrm{CN}$ of MAA & $\mathrm{CH}_{2}$ of $\mathrm{AmM}(\mathrm{Ha})$ & $119.81 / 2.05$ \\
\hline 52 & $\mathrm{CN}$ of MAA & $\mathrm{CH}_{2}$ of $\mathrm{AmM}(\mathrm{Hb})$ & $119.81 / 1.76$ \\
\hline 53 & $\mathrm{CN}$ of MAA & $\mathrm{CH}_{2}$ of $\mathrm{ArA}$ & $119.65 / 1.90$ \\
\hline 54 & $\mathrm{CN}$ of MAA & $\mathrm{CH}_{2}$ of $\mathrm{AmA}(\mathrm{Ha})$ & $119.58 / 2.10$ \\
\hline 55 & $\mathrm{CN}$ of MAA & $\mathrm{CH}_{2}$ of $\mathrm{AmA}(\mathrm{Hb})$ & $119.58 / 1.85$ \\
\hline
\end{tabular}

the coupling of methine protons of MAA triad with methylene protons as shown in Figure 10a. In the HMBC spectra of copolymer having higher acrylonitrile content (Figure 10b), three additional cross peaks 53-55 were obtained due to the coupling of nitrile carbon of MAA triad with the ArA, AmA $(\mathrm{Ha})$, and $\mathrm{AmA}(\mathrm{Hb})$ methylene protons.

The comparison of theoretical and experimental values of A-centered triad fractions for nitrile carbon resonance patterns is listed in Table VI. The gradiency in the copolymers was explored by analyzing the trend of A centered triad fractions with conversion.

The two-dimensional HSQC, TOCSY, and HMBC NMR spectra of different compositions of poly(acrylonitrile-co-2-methoxyethyl acrylate) enabled the complete spectral assignments of proton and carbon resonances.

\section{CONCLUSIONS}

ATRP of acrylonitrile and 2-methoxyethyl acrylate was performed successfully with 2-bromopropionitrile as initiator and $\mathrm{CuCl} /$ bpy as catalyst system in ethylene carbonate at $60{ }^{\circ} \mathrm{C}$. Kinetic studies and molecular weight distribution data indicated towards the 
Table V. Comparison of M-centered triad fractions determined from carbonyl carbon resonance patterns

\begin{tabular}{|c|c|c|c|c|c|c|}
\hline \multicolumn{7}{|c|}{$\mathrm{f}_{\mathrm{A}}=0.30$} \\
\hline \multirow{2}{*}{ Conversion } & \multicolumn{6}{|c|}{ Triad fractions } \\
\hline & \multicolumn{3}{|c|}{ Theoretical } & \multicolumn{3}{|c|}{ Experimental } \\
\hline & MMM & MMA+AMM & AMA & MMM & $\mathrm{MMA}+\mathrm{AMM}$ & AMA \\
\hline 0.17 & 0.354 & 0.482 & 0.164 & 0.351 & 0.479 & 0.170 \\
\hline 0.32 & 0.367 & 0.477 & 0.156 & 0.370 & 0.475 & 0.155 \\
\hline 0.55 & 0.393 & 0.467 & 0.140 & 0.390 & 0.470 & 0.140 \\
\hline 0.68 & 0.411 & 0.458 & 0.131 & 0.413 & 0.460 & 0.127 \\
\hline 0.82 & 0.437 & 0.444 & 0.119 & 0.440 & 0.442 & 0.118 \\
\hline \multicolumn{7}{|c|}{$\mathrm{f}_{\mathrm{A}}=0.45$} \\
\hline \multirow{3}{*}{ Conversion } & \multicolumn{6}{|c|}{ Triad fractions } \\
\hline & \multicolumn{3}{|c|}{ Theoretical } & \multicolumn{3}{|c|}{ Experimental } \\
\hline & MMM & $\mathrm{MMA}+\mathrm{AMM}$ & AMA & MMM & $\mathrm{MMA}+\mathrm{AMM}$ & AMA \\
\hline 0.26 & 0.193 & 0.493 & 0.314 & 0.190 & 0.495 & 0.315 \\
\hline 0.40 & 0.203 & 0.494 & 0.303 & 0.205 & 0.496 & 0.299 \\
\hline 0.50 & 0.211 & 0.495 & 0.294 & 0.209 & 0.496 & 0.295 \\
\hline 0.64 & 0.225 & 0.496 & 0.279 & 0.227 & 0.495 & 0.278 \\
\hline 0.78 & 0.243 & 0.495 & 0.262 & 0.240 & 0.493 & 0.267 \\
\hline \multicolumn{7}{|c|}{$\mathrm{f}_{\mathrm{A}}=0.60$} \\
\hline \multirow{3}{*}{ Conversion } & \multicolumn{6}{|c|}{ Triad fractions } \\
\hline & \multicolumn{3}{|c|}{ Theoretical } & \multicolumn{3}{|c|}{ Experimental } \\
\hline & MMM & $\mathrm{MMA}+\mathrm{AMM}$ & AMA & MMM & $\mathrm{MMA}+\mathrm{AMM}$ & AMA \\
\hline 0.20 & 0.087 & 0.416 & 0.497 & 0.082 & 0.419 & 0.499 \\
\hline 0.36 & 0.093 & 0.423 & 0.484 & 0.090 & 0.421 & 0.489 \\
\hline 0.48 & 0.098 & 0.429 & 0.473 & 0.100 & 0.429 & 0.471 \\
\hline 0.66 & 0.108 & 0.438 & 0.454 & 0.106 & 0.441 & 0.453 \\
\hline 0.85 & 0.125 & 0.450 & 0.425 & 0.127 & 0.446 & 0.427 \\
\hline
\end{tabular}

Table VI. Comparison of A-centered triad fractions determined from nitrile carbon resonance patterns

\begin{tabular}{|c|c|c|c|c|c|c|}
\hline \multicolumn{7}{|c|}{$\mathrm{f}_{\mathrm{A}}=0.30$} \\
\hline \multirow{3}{*}{ Conversion } & \multicolumn{6}{|c|}{ Triad fractions } \\
\hline & \multicolumn{3}{|c|}{ Theoretical } & \multicolumn{3}{|c|}{ Experimental } \\
\hline & AAA & AAM+MAA & MAM & AAA & AAM+MAA & MAM \\
\hline 0.17 & 0.147 & 0.473 & 0.380 & 0.145 & 0.476 & 0.379 \\
\hline 0.32 & 0.139 & 0.467 & 0.394 & 0.140 & 0.469 & 0.391 \\
\hline 0.55 & 0.125 & 0.455 & 0.420 & 0.126 & 0.452 & 0.422 \\
\hline 0.68 & 0.116 & 0.445 & 0.439 & 0.115 & 0.446 & 0.439 \\
\hline 0.82 & 0.106 & 0.430 & 0.464 & 0.108 & 0.431 & 0.461 \\
\hline \multicolumn{7}{|c|}{$\mathrm{f}_{\mathrm{A}}=0.45$} \\
\hline \multirow{3}{*}{ Conversion } & \multicolumn{6}{|c|}{ Triad fractions } \\
\hline & \multicolumn{3}{|c|}{ Theoretical } & \multicolumn{3}{|c|}{ Experimental } \\
\hline & AAA & $\mathrm{AAM}+\mathrm{MAA}$ & MAM & AAA & AAM+MAA & MAM \\
\hline 0.26 & 0.289 & 0.497 & 0.214 & 0.290 & 0.495 & 0.215 \\
\hline 0.40 & 0.278 & 0.498 & 0.224 & 0.275 & 0.498 & 0.227 \\
\hline 0.50 & 0.269 & 0.499 & 0.232 & 0.270 & 0.501 & 0.229 \\
\hline 0.64 & 0.255 & 0.498 & 0.247 & 0.255 & 0.499 & 0.246 \\
\hline 0.78 & 0.239 & 0.495 & 0.266 & 0.240 & 0.493 & 0.267 \\
\hline \multicolumn{7}{|c|}{$\mathrm{f}_{\mathrm{A}}=0.60$} \\
\hline \multirow{3}{*}{ Conversion } & \multicolumn{6}{|c|}{ Triad fractions } \\
\hline & \multicolumn{3}{|c|}{ Theoretical } & \multicolumn{3}{|c|}{ Experimental } \\
\hline & AAA & AAM+MAA & MAM & AAA & AAM+MAA & MAM \\
\hline 0.20 & 0.470 & 0.431 & 0.099 & 0.471 & 0.430 & 0.099 \\
\hline 0.36 & 0.457 & 0.438 & 0.105 & 0.452 & 0.440 & 0.108 \\
\hline 0.48 & 0.446 & 0.443 & 0.111 & 0.448 & 0.442 & 0.110 \\
\hline 0.66 & 0.427 & 0.452 & 0.121 & 0.428 & 0.454 & 0.118 \\
\hline 0.85 & 0.399 & 0.461 & 0.140 & 0.401 & 0.460 & 0.139 \\
\hline
\end{tabular}


presence of constant concentration of active species throughout the polymerization. The reactivity ratios calculated $\left(\mathrm{r}_{\mathrm{A}}=1.52, \mathrm{r}_{\mathrm{M}}=0.60\right)$ were in good agreement with those known for conventional free radical copolymerization. A comprehensive microstructure analysis of $\mathrm{A} / \mathrm{M}$ copolymers was done by the correlation of $1 \mathrm{D}\left({ }^{1} \mathrm{H},{ }^{13} \mathrm{C}\left\{{ }^{1} \mathrm{H}\right\}\right.$, DEPT) and 2D (HSQC, TOCSY, HMBC) NMR spectroscopy. 2D HSQC spectral analysis facilitated in analyzing the assignments of the methine carbon resonances from both $\mathrm{A}$ and $\mathrm{M}$ units up to triad level. These assignments were further confirmed by 2D TOCSY spectral analysis. The complete spectral assignments for the quaternary carbons, viz., carbonyl and nitrile carbons were done with the help of 2D HMBC NMR spectral studies. This work hence presented the importance of 2D NMR analysis in understanding the microstructure of polymers.

Acknowledgment. One of the authors (Tripta Saini) thanks the Council of Scientific and Industrial Research (CSIR), New Delhi, India for providing the financial support.

\section{REFERENCES}

1. K. Matyjaszewski and J. Xia, Chem. Rev., 101, 2921 (2001).

2. M. Sawamoto, M. Kamigaito, and T. Ando, Chem. Rev., 101, 3689 (2001).

3. S. Perrier and P. Takolpuckdee, J. Polym. Sci., Part A: Polym. Chem., 43, 5347 (2005).

4. D. H. Solomon, J. Polym. Sci., Part A: Polym. Chem., 43, 5748 (2005).

5. V. Coessens, T. Pintauer, and K. Matyjaszewski, Prog. Polym. Sci., 26, 337 (2001).

6. A. Limer, A. Heming, I. Shirley, and D. M. Haddleton, Eur. Polym. J., 41, 805 (2005).

7. T. Pintauer and K. Matyjaszewski, Coord. Chem. Rev., 249, 1155 (2005).

8. C. F. Huang, H. F. Lee, S. W. Kuo, H. Xu, and F. C. Chang, Polymer, 45, 2261 (2004).

9. B. S. Shemper and L. J. Mathias, Eur. Polym. J., 40, 651 (2004).

10. G. Deng, L. Zhang, C. Liu, L. He, and Y. Chen, Eur. Polym. J., 41, 1177 (2005).

11. R. Venkatesh, F. Vergouwen, and B. Klumperman, Macromol. Chem. Phys., 206, 547 (2005).

12. S. Monge, V. Darcos, and D. M. Haddleton, J. Polym. Sci., Part A: Polym. Chem., 42, 6299 (2004).

13. A. M. Oz-Bonilla, E. L. Madruga, and M. Fernandez-Garcia, J. Polym. Sci., Part A: Polym. Chem., 43, 71 (2005).

14. R. Paris and J. L. De La Fuente, J. Polym. Sci., Part A: Polym. Chem., 43, 2395 (2005).

15. B. L. K. Denizli, J. Lutz, L. Okrasa, T. Pakula, A. Guner, and K. Matyjaszewski K., J. Polym. Sci., Part A: Polym. Chem., 43, 3440 (2005).

16. T. Biedron and P. Kubisa, J. Polym. Sci., Part A: Polym.
Chem., 43, 3454 (2005).

17. K. Ibrahim, B. Lofgren, and J. Seppala, Eur. Polym. J., 39, 939 (2003).

18. K. Demirelli, A. Kurt, and M. Coskun, Eur. Polym. J., 40, 451 (2004).

19. Y. Xu, J. Lu, O. Xu, and L. Wang, Eur. Polym. J., 41, 2422 (2005).

20. I. Ydens, S. Moins, P. Degee, and P. Dubois, Eur. Polym. J., 41, 1502 (2005).

21. R. M. Kris, Vidts, and Filip E Du Prez., Eur. Polym. J., 42, 43 (2006).

22. J. Bibiao, F. Jianbo, Y. Yang, R. Oiang, W. Wenyun, and H. Jianjun, Eur. Polym. J., 42, 179 (2006).

23. C. Zhu, F. Sun, M. Zhang, and J. Jin, Polymer, 45, 1141 (2004).

24. S. Nanjundan, C. S. Unnithan, C. S. J. Selvamalar, and A. Penlidis, React. Funct. Polym., 62, 11 (2005).

25. J. Huang and K. Matyjaszewski, Macromolecules, 38, 3577 (2005).

26. N. K. Singha, B. Ruiter, and U. S. Schubert, Macromolecules, 38, 3596 (2005).

27. Q. Smith, J. Huang, K. Matyjaszewski, and Y. L. Loo, Macromolecules, 38, 5581 (2005).

28. A. S. Brar and T. Saini, J. Polym. Sci., Part A: Polym. Chem., 43, 2810 (2005).

29. A. S. Brar and T. Saini, J. Polym. Sci., Part A: Polym. Chem., 44, 1975 (2006).

30. W. C. Lin, T. Y. Liu, and M. C. Yang, Biomaterials, 25, 1947 (2004).

31. L. S. Wan, Z. K. Xu, X. J. Huang, Z. G. Wang, and J. L. Wang, Polymer, 46, 7715 (2005).

32. B. Jung, J. Membr. Sci., 229, 129 (2004).

33. M. C. Yang and T. Y. Liu, J. Membr. Sci., 226, 119 (2003).

34. T. Godjevargova, V. Konsulov, and A. Dimov, J. Membr. Sci., 152, 235 (1999).

35. M. Tanaka, T. Motomura, M. Kawada, T. Anzai, Y. Kasori, T. Shiroya, K. Shimura, M. Onishi, and A. Mochizuki, Biomaterials, 21, 1471 (2000).

36. M. Tanaka, A. Mochizuki, N. Ishii, T. Motomura, and T. Hatakeyama, Biomacromolecules, 3, 36 (2002).

37. A. S. Brar and S. Kaur, J. Polym. Sci., Part A: Polym. Chem., 43, 1100 (2005).

38. A. S. Brar and S. Kaur, Polym. J., 37, 316 (2005).

39. K. Matyjaszewski, M. Ziegler, S. V. Arehart, D. Greszta, and T. Pakula, J. Phys. Org. Chem., 13, 775 (2000).

40. I. S. Kattimuttathu, S. S. Bhamidipalli, and V. S. N. R. Kothapally, Macromol. Mater. Eng., 288, 980 (2003).

41. A. F. Garcia and E. L. Madruga, J. Polym. Sci., Part A: Polym. Chem., 35, 1961 (1997).

42. C. Arias, M. M. C. L. Gonzalez, M. F. Garcia, J. M. B. Rienda, and E. L. Madruga, Polymer, 34, 7186 (1993).

43. A. Staubli, E. Mathiowitz, and R. Langer, Macromolecules, 24, 2291 (1991).

44. K. Matsuzaki, T. Uryu, and T. Asakura, "NMR Spectroscopy and Stereoregularity of Polymers," Japan Sci. Soc. Press, Tokyo, 1996, Chapter 4.

45. F. A. Bovey and P. A. Mirau, "NMR of Polymers," Academic Press, San Diego, 1996, Chapter 3.

46. J. L. Fuente, M. F. Garcia, M. F. Sanz, and E. L. Madruga, 
Macromolecules, 34, 5833 (2001).

47. Y. Kim and H. J. Harwood, Polymer, 43, 3229 (2002).

48. T. W. Shyr, C. M. Lo, and S. R. Ye, Polymer, 46, 5284 (2005).

49. H. S. Bisht, S. S. Ray, and A. K. Chatterjee, J. Polym. Sci., Part A: Polym. Chem., 41, 1864 (2003).

50. H. Ito and D. C. Miller, J. Polym. Sci., Part A: Polym. Chem., 42, 1468 (2004).

51. K. B. Wiles, V. A. Bhanu, A. J. Pasquale, T. E. Long, and J. E. McGrath, J. Polym. Sci., Part A: Polym. Chem., 42, 2994 (2004).

52. A. S. Brar and T. Saini, J. Polym. Sci., Part A: Polym. Chem., 44, 2955 (2006).

53. S. J. Oh, D. R. Kinney, W. Wang, and P. L. Rinaldi, Macromolecules, 35, 2602 (2002).

54. F. J. Wyzgoski, P. L. Rinaldi, E. F. McCord, M. A. Stewart, and D. R. Marshall, Macromolecules, 37, 846 (2004).

55. A. S. Brar, G. Singh, and R. Shankar, J. Mol. Struct., 703, 69
(2004).

56. A. S. Brar, G. Singh, and R. Shankar, Polymer, 46, 7164 (2005).

57. C. Tang, T. Kowalewski, and K. Matyjaszewski, Macromolecules, 36, 1465 (2003).

58. M. Lazzari, O. Chiantore, R. Mendichi, and M. A. LopezQuintela, Macromol. Chem. Phys., 206, 1382 (2005).

59. N. V. Tsarevsky, T. Sarbu, B. Gobelt, and K. Matyjaszewski, Macromolecules, 35, 6142 (2002).

60. M. Fineman and S. D. Ross, J. Polym. Sci., 5, 259 (1950).

61. T. Kelen and F. Tudos, J. Macromol. Sci. Chem., A9, 1 (1975).

62. A. S. Brar, G. Singh, and R. Shankar, Eur. Polym. J., 40, 2679 (2004).

63. F. Heatley, G. Yu, C. Booth, and T. G. Blease, Eur. Polym. J., 27, 573 (1991).

64. R. Mao and M. B. Huglin, Polymer, 34, 1709 (1993). 